\title{
Black Pod: Diverse Pathogens with a Global Impact on Cocoa Yield
}

\author{
David Guest
}

University of Sydney, NSW 2006, Australia.

\begin{abstract}
Guest, D. 2007. Black pod: Diverse pathogens with a global impact on cocoa yield. Phytopathology 97:1650-1653.

Pathogens of the Straminipile genus Phytophthora cause significant disease losses to global cocoa production. P. megakarya causes significant pod rot and losses due to canker in West Africa, whereas P. capsici and $P$. citrophthora cause pod rots in Central and South America. The global and highly damaging $P$. palmivora attacks all parts of the cocoa tree at all stages of the growing cycle. This pathogen causes 20 to $30 \%$ pod losses through black pod rot, and kills up to $10 \%$ of trees annually through stem cankers. P. palmivora has a complex disease cycle involving

several sources of primary inoculum and several modes of dissemination of secondary inoculum. This results in explosive epidemics during favorable environmental conditions. The spread of regional pathogens must be prevented by effective quarantine barriers. Resistance to all these Phytophthora species is typically low in commercial cocoa genotypes. Disease losses can be reduced through integrated management practices that include pruning and shade management, leaf mulching, regular and complete harvesting, sanitation and pod case disposal, appropriate fertilizer application and targeted fungicide use. Packaging these options to improve uptake by smallholders presents a major challenge for the industry.
\end{abstract}

The Straminipile genus Phytophthora probably causes more production losses globally than any other disease of cocoa. P. palmivora has several hundred recorded hosts and is of universal importance in cocoa, causing global yield losses up to 20 to $30 \%$ and tree deaths of up to $10 \%$ annually, although individual farms in wetter cocoa-growing areas may suffer total loss $(6,7,11,20)$. $P$. megakarya is now the most important cocoa pathogen in Central and West Africa, frequently causing total loss of pods $(11,22)$. It is endemic to Equatorial Guinea, Gabon, Cameroon, Togo, Nigeria, and Ghana, and is still in an invasive phase in neighboring Côte d'Ivoire (16). P. capsici and P. citrophthora pod rots are common in Central and South America and may cause significant losses under favorable environments (7). Other species including $P$. megasperma and $P$. katsurae have also been reported to cause pod rots. Significantly, the two major species, $P$. palmivora and $P$. megakarya, originated away from the centre of diversity of cocoa, and are thus "new encounter" diseases.

Disease symptoms and pathogen biology. The most striking symptom caused by Phytophthora spp. is pod rot or black pod (Figs. 1 and 2). Pod lesions begin as small, hard, dark spots on any part of the pod, at any stage of pod development. Lesions grow rapidly covering the entire pod surface and internal tissues, including the beans, of susceptible genotypes within a few days. Colonized pods shrivel to form a mummified pod, which in the case of $P$. palmivora provides a reservoir of inoculum for at least 3 years (4). Under humid conditions a single pod may produce up to 4 million sporangia (containing motile zoospores) that are disseminated by rain, ants, flying insects, rodents, bats, and flying foxes; on contaminated harvesting and pruning implements; and in contaminated soil (11). Pod rot symptoms due to P. megakarya

Corresponding author: D. Guest; E-mail address: d.guest@usyd.edu.au

* The $\boldsymbol{e}$-Xtra logo stands for "electronic extra" and indicates that the online version contains supplemental material not included in the print edition. Figures 1, 2, and 3 appear in color online

doi:10.1094/PHYTO-97-12-1650

(C) 2007 The American Phytopathological Society are very similar but symptoms appear quicker and sporulation is usually more abundant $(11,22)$ (Fig. 2).

$P$. palmivora and $P$. megakarya infect bark, flower cushions, and chupons causing cankers. Cankers at the base of the trunk may extend to the main roots. Canker lesions are hidden by the bark but often exude a reddish gum or infect flower cushions, killing the flowers. Scraping the surface of the bark reveals a discrete spreading reddish lesion in the inner bark that usually does not penetrate deep into the wood (Fig. 3). The significance of Phytophthora stem canker is probably underestimated, as cankers reduce tree vigor and pod carrying capacity, thus reducing yield. Cankers may also provide an important source of inoculum for pod rot $(11,12)$. Canker development is often associated with stem and bark borers, including the longicorn beetle (Glenea spp.) and Pantorhytes spp., which may be attracted to them. Girdling cankers cause the sudden death of up to $10 \%$ of trees each year, reducing production and imposing an extra cost in replanting and lost production as replanted trees mature.

In humid conditions, $P$. palmivora also causes seedling and leaf blight. Infections of fine roots are also common, however these appear to be more important as a source of inoculum than as a cause of serious injury to the tree, particularly if a leaf mulch layer is present.

Sexual reproduction requires two mating types (A1 and A2) in the heterothallic species $P$. megakarya and $P$. palmivora, however oospores are rarely observed in nature, possibly because opposite mating types are rarely found together (1). There is some evidence of natural hybrids where compatible mating types of $P$. palmivora and $P$. megakarya co-exist (8). The pathogen commonly survives as mycelium and chlamydospores (thick-walled resistant spores) in infected plant material, usually roots, cankers or mummified pods (P. palmivora), or in the soil ( $P$. megakarya) (11).

Epidemiology. Although symptoms appear year-round, the most severe epidemics coincide with the proliferation of sporangia and insect vectors during the wet season. In the presence of moisture, sporangia release the infective propagules, zoospores. Zoospores need 20 to $30 \mathrm{~min}$ in free water on plant surfaces before 
they encyst, germinate, and penetrate host tissues. Under favorable conditions sporangia develop within $48 \mathrm{~h}$ of infection.

As a soilborne pathogen that infects the aerial parts of cocoa trees, the key epidemiological question is how the pathogen reaches into the canopy. $P$. palmivora survives less than 10 months in soil as a saprophyte, depending on the ground cover (17). Rain splash, aerosols, contaminated equipment, rodents, and ants are potential mechanisms of inoculum movement into the canopy. However, rain splash dispersal of $P$. palmivora from the soil surface or piles of pod cases is limited to $75 \mathrm{~cm}$, and there is little evidence to indicate that aerosols are created under the relatively protected canopy of cocoa trees (11). Once in the canopy, reservoirs of inoculum are established in cankers, in infected flower cushions and mummified pods. However, in their detailed study in Nigeria, Gregory and Maddison (11) concluded that when all the known pathogen dissemination mechanisms were tallied, up to $40 \%$ of pod rot lesions resulted from "no obvious source" (11).

The recent report from Papua New Guinea that flying beetles carry inoculum into the canopy, and especially to pods, may resolve the origin of infections with "no obvious source", and requires confirmation in other cocoa growing areas (18). Beetles colonize Phytophthora lesions on pods of susceptible cultivars more rapidly and more extensively than on less susceptible cultivars, and identification of the factors involved, possibly attractants in susceptible genotypes or repellents in resistant genotypes, could be useful for breeding programs.

By contrast, the soilborne phase of $P$. megakarya is dominant. Root infections maintain a reservoir of inoculum that releases zoospores into the soil surface water. Zoospores spread by rain splash, stepwise up the plant, from pods closest to the ground until the entire tree is affected. P. megakarya does not survive in mummified pods but remains viable in bark and sapwood for several months and in infected debris for at least 18 months, Brasier et al. (11).

Disease management. Quarantine. Whereas P. palmivora is globally distributed, pathogenic diversity within the species exists and the introduction of exotic isolates poses a significant threat to cocoa production $(1,6)$. Efforts should be made to prevent the movement of Phytophthora spp., particularly P. megakarya from West Africa to other cocoa-growing regions. The movement of soil between cocoa-growing areas must be avoided and cocoa germplasm must be exchanged thorough intermediate quarantine facilities $(16,22)$.

Resistance. Breeding for resistance offers the best long-term management strategy; however, progress incorporating durable resistance into cultivars with desirable agronomic and quality

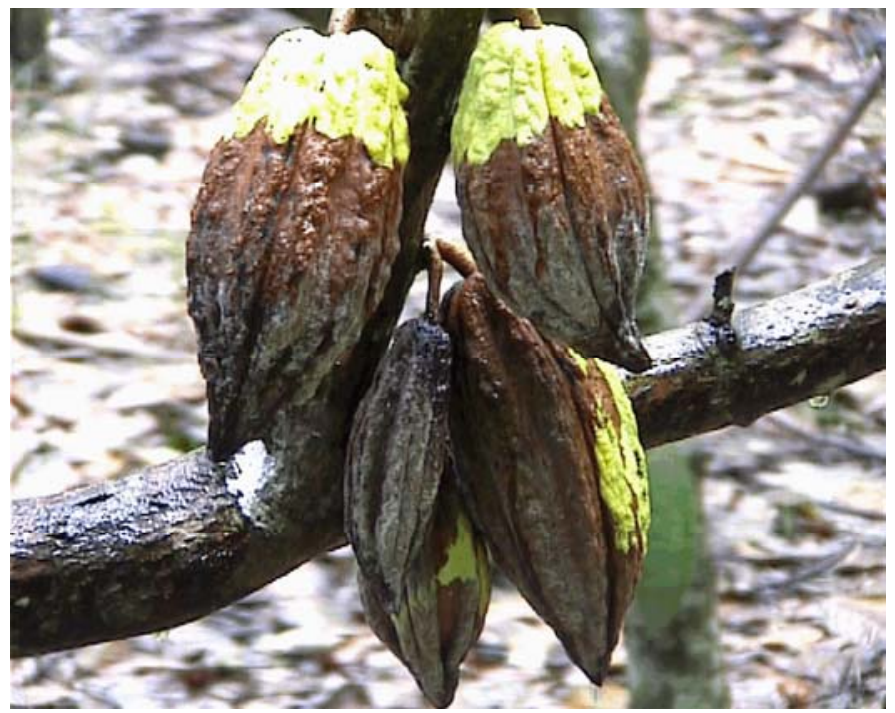

Fig. 1. Pod rot caused by Phytophthora palmivora. attributes has been slow. As a genetically variable perennial tree, cocoa improvement presents significant challenges to breeders. Additionally, most breeding programs have focused on yield and quality under intense management regimes and correspondingly low rates of disease, thus neglecting the impact of disease on yields under smallholder farm conditions.

Amelonado-type Lower Amazon and Upper Amazon selections appear less susceptible to Phytophthora than Trinitario and Criollo types, and are widely used in breeding programs (15). Reliable screening assays for resistance using detached leaves or pods have been developed and correlate well with field observations of pod rot incidence $(13,14,24)$. These assays are now used in breeding programs to identify and cull highly susceptible progenies.

Resistance to Phytophthora has been identified as additive and polygenic $(5,10)$ and does not appear specific for at least the two most important species of Phytophthora, $P$. palmivora and $P$. megakarya (21). A number of different quantitative trait loci (QTLs) for resistance to Phytophthora have been identified in leaf disk, pod inoculation, and field studies, although so far none of these markers appear consistently (9). Nevertheless, with further development and improved precision, marker assisted selection for resistance should assist future cocoa breeding programs.

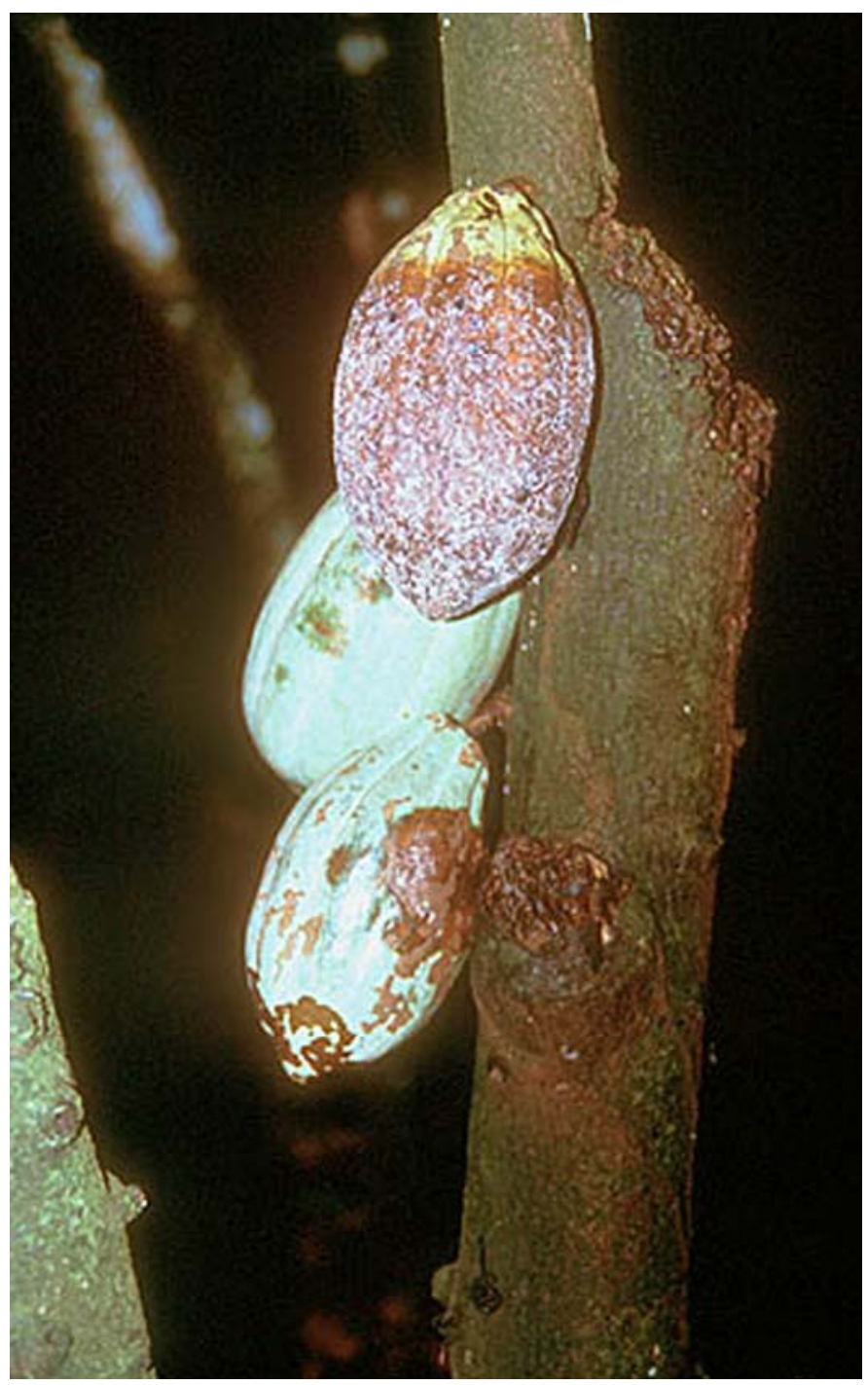

Fig. 2. Pod rot caused by Phytophthora megakarya (Courtesy P. R. Tondje; Reprinted from Bowers, J. H., Bailey, B. A., Hebbar, P. K., Sanogo, S., and Lumsden, R. D., 2001, The impact of plant diseases on world chocolate production, Online, Plant Health Progress, doi:10.1094/PHP-2001-0709-01-RV). 
An alternative approach to identifying resistance is to seek out healthy individual trees among the great diversity of genotypes on farms under high natural disease pressure. The genetic diversity resulting from germplasm introductions over time and natural crossing has generated stunning examples of segregation for different levels of susceptibility in neighboring trees (19). Once identified and validated in genotype-environment trials, these individuals can be used to provide budwood for farm renovation and for inclusion in breeding programs.

Biological control. There has been extensive research into the discovery and application of conventional inundative biological control agents against Phytophthora diseases of cocoa. Although there have been many reports of antagonistic and mycoparasitic fungi inhibiting the growth of Phytophthora in vitro, no commercial products have been released or widely adopted by cocoa farmers. The short life cycle, phenomenal reproductive capacity, complex disease cycle, and zoospore motility of Phytophthora generates explosive epiphytotics in cocoa have so far rendered inundative biological control agents ineffective.

The discovery and development of antagonistic endophytes offers more promise. Endophytic fungi are naturally transmitted from mature trees to seedlings in the natural cocoa forest ecosystem, however they eventually disappear from plantations. Recent evidence suggests that antagonistic endophytes re-introduced into cocoa persist and protect the tree against Phytophthora (2). Endophytes could play an important role in integrated disease and pest management programs.

Biological suppression and antagonism following the use of mulches and composts improves soil health and microbial activity and suppresses Phytophthora, and these methods are also important components of integrated management programs $(3,17)$.

Fungicides. Chemicals are widely recommended for Phytophthora control, but their effectiveness is variable, particularly during high-disease pressure in the wet season. The implementation of recommendations is typically yield- and price-sensitive. Protectant sprays of copper-based fungicides, together with the systemic fungicide metalaxyl, at 3- or 4-weekly intervals are fre-

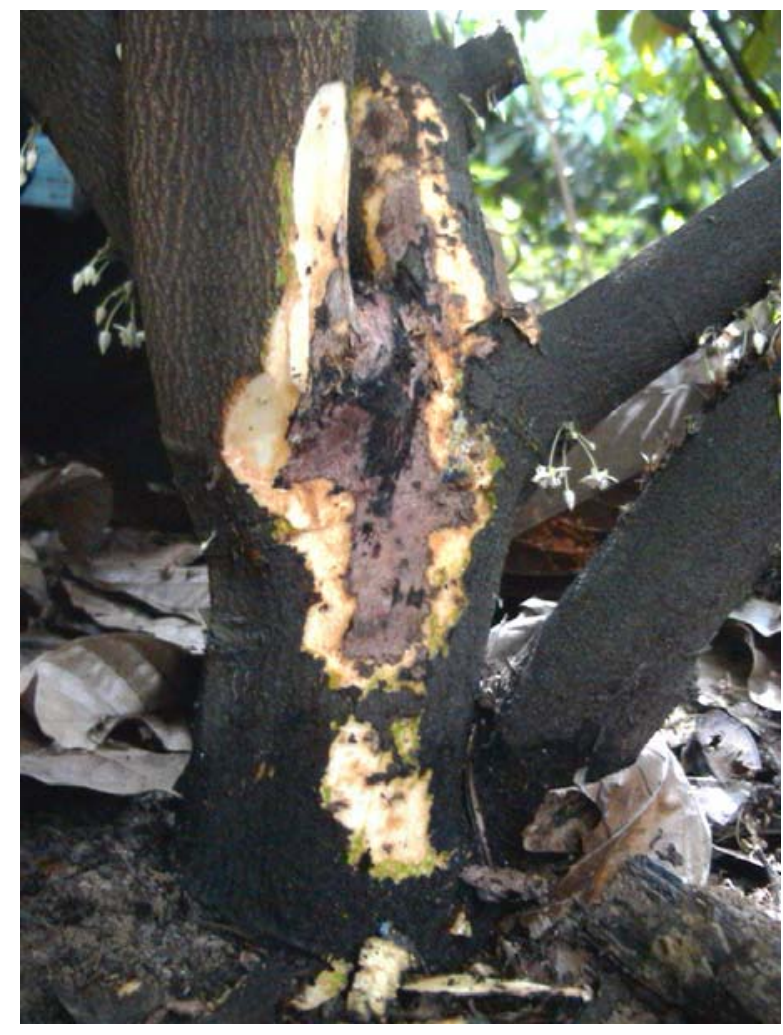

Fig. 3. Cacao stem canker caused by Phytophthora palmivora. quently recommended, but rarely cost-effective (12). Annual trunk injections of the inexpensive inorganic salt potassium phosphonate are very effective against $P$. palmivora, particularly in reducing cankers, in very wet areas of Papua New Guinea (PNG) (12), and in Ghana against both $P$. palmivora and P. megakarya (23). Canker control can also be achieved by scraping surface bark to expose the canker, then painting the affected area with a copper fungicide.

Integrated management. Disease management strategies should focus on eliminating sources of primary inoculum, in preventing the movement of inoculum from the soil to the canopy, and in reducing the production of secondary inoculum. Also, unlike $P$. palmivora, the growth of $P$. megakarya is inhibited by light. Shade and canopy management practices that increase light and airflow within the canopy, such as appropriate spacing, pruning, and weed control, are also likely to increase flowering and pod development. Frequent and complete harvesting, sanitation, and appropriate disposal of pod mummies, infected pods, and pod husks will reduce the levels of inoculum and flying beetle vectors. Piles of pod husks provide breeding sites for insect vectors and discarded husks should be buried, preferably with the addition of supplements that promote microbial activity and rapid decomposition, such as chicken manure (3). Sanitation should also include removal of ant tents (soil tunnels built on the trunk surface by ants) that spread inoculum into the canopy.

Leaf litter mulches and ground covers reduce disease by presenting a barrier to rain splash and by promoting the microbial decomposition of Phytophthora-infected debris (17).

Care is needed to fully integrate Phytophthora management into overall farm management. Whereas cultural control has been shown to be effective in areas of Ghana where P. palmivora is the only cause of black pod, canopy management, weed control, and frequent harvesting alone did not control $P$. megakarya in Cameroon (20). However, when combined with fungicide applications, sanitation provides useful control of both Phytophthora species (23). Integrated disease management practices offer the best promise of effective control of Phytophthora spp.; however, these strategies depend on a thorough understanding of the biology of the pathogen, the cropping cycle of the host under local conditions and the education and active participation of farmers.

In PNG farmers are presented with a series of integrated disease and pest management options that are demonstrated during field days and training programs (Table 1). However, the choice of an option is considered, decided and implemented by the farmer. Early results indicate a high level of interest and adoption of these options, with impressive increases in yield.

TABLE 1. Integrated disease and pest management options for smallholders ${ }^{\mathrm{a}}$

\begin{tabular}{llc}
\hline Input level & \multicolumn{1}{c}{ Activity } & $\begin{array}{c}\text { Predicted yield } \\
(\mathrm{kg} \mathrm{db} / \mathrm{ha})\end{array}$ \\
\hline Low & Current smallholder practice & 1.1 \\
Medium & Cocoa and shade tree pruning & 2.0 \\
& $\begin{array}{l}\text { Weekly harvests and sanitation } \\
\text { Weed control }\end{array}$ & \\
High & Cocoa and shade tree pruning & 2.5 \\
& Weekly harvests and sanitation & \\
& Weed control & \\
& Fertilizers and manures & \\
Maximum & Canker treatment & 3.3 \\
& Cocoa and shade tree pruning & \\
& Weekly harvests and sanitation & \\
& Weed control & \\
& Fertilizers and manures & \\
& Canker treatment & \\
& Insect vector control & \\
\hline
\end{tabular}

a Predicted yields are based on results over 12 months on a farmer trial in East New Britain Province (Papua New Guinea Cocoa Coconut Institute, 2007). 


\section{CONCLUSIONS}

Integrated disease management options should be developed and promoted for smallholders in each region. P. megakarya poses a significant threat to cocoa-growing regions outside West Africa, and a concerted integrated global breeding program is in progress to identify potential sources of resistance and other options for management.

The complex issues of Phytophthora, soil health and sustainability of production need to be addressed in future research. Healthy soils are characterized by high organic matter and plant nutrient contents, abundant and diverse microbial activity, good drainage and physical structure, and low levels of pathogen inoculum. Understanding how to achieve and maintain healthy soils on cocoa farms is fundamental to sustaining higher yields and lower levels of disease, while minimizing environmental damage.

\section{LITERATURE CITED}

1. Appiah, A., Flood, J., Bridge, P. D., and Archer, S. A. 2003. Inter and intra specific morphometric variation and characterization of Phytophthora isolates from cocoa. Plant Pathol. 52:168-180.

2. Arnold, A. E., Mejía, L. C., Kyllo, D., Rojas, E. I., Maynard, Z., Robbins, N., and Herre, E. A. 2002. Fungal endophytes limit pathogen damage in a tropical tree. Proc. Natl. Acad. Sci. 100:15649-15654.

3. Aryantha, I. P., Cross, R., and Guest, D. I. 2000. Suppression of Phytophthora cinnamomi in potting mixes amended with uncomposted and composted animal manures. Phytopathology 90:775-782.

4. Dennis, J. J. C., and Konam, J. K. 1994. Phytophthora palmivora: Cultural control methods and their relationship to disease epidemiology on cocoa in PNG. Pages 953-957 in: Proceedings of the 11th International Cocoa Research Conference, Cocoa Producers Alliance, London.

5. Despreaux, D., Clement, D., and Partiot, M. 1989. La pourriture brune des cabosses du cacaoyer au Cameroun: Mise en évidence ed'un caractère de rèsistance au champ. Agronomie 9:683-691.

6. Drenth, A., and Guest, D. I. 2004. Phytophthora in the tropics. Page 238 in: Diversity and Management of Phytophthora in Southeast Asia. A. Drenth and D. I. Guest, eds. ACIAR Monograph No. 114. ACIAR, Canberra, Australia.

7. Erwin, D. C., and Ribeiro, O. K., eds. 1996. Phytophthora Diseases Worldwide. American Phytopathological Society, St. Paul, MN.

8. Espirito Santo, S. N., Deus Lima, A. M., and Bastide, P. 2001. Spatial distribution of P. palmivora and P. megakarya in Sao Tome and Principe. Proceedings of the 13th International Cocoa Research Conference, 2000. Kota Kinabalu, Malaysia.

9. Figueira, A. 2004. New methodologies for cocoa breeding. In: Cocoa Futures. J. Flood and R. Murphy, eds. CABI-FEDERACAFE, USDA.

10. Flament, M. H., Kébé, I., Clément, D., Pieretti, I., Rustericci, A. M., N'Goran, J. A. K., Cilas, C., Despreaux, D., and Lanaud, C. 2001. Ge- netic mapping of resistance to Phytophthora palmivora in cocoa. Genome 44:79-85.

11. Gregory, P. H. and Maddison, A. C., eds. 1981 Epidemiology of Phytophthora on Cocoa in Nigeria. CAB International, Wallingford, UK.

12. Guest, D. I., Anderson, R. D., Foard, H. J., Phillips, D., Worboys, S., and Middleton, R. M. 1994. Long-term control of Phytophthora diseases of cocoa using trunk-injected phosphonate. Plant Pathol. 43: 479-492.

13. Iwaro, A. D., Sreenivasan, T. N., and Umaharan, P. 1997. Foliar resistance to Phytophthora palmivora as an indicator of pod resistance in Theobroma cacao. Plant Dis. 81:619-624.

14. Iwaro, A. D., Thévenin, J. M., Butler, D. R., and Eskes, A. B. 2005. Usefulness of the detached pod test for the assessment of cacao pod resistance to Phytophthora pod rot. Eur. J. Plant Pathol. 113:173-182.

15. Iwaro, A. D., Butler, D. R., and Eskes, A. B. 2006. Sources of resistance to Phytophthora pod rot at the International Cocoa Genebank, Trinidad. Genet. Resour. Crop Evol. 53:99-109.

16. Kébé, I. B., N'Guessan, F. K., Keli, J. Z., and Bekon, A. K. 2002. Cocoa IPM research and implementation in Cote d'Ivoire. In: Proceedings of the West African Regional Cocoa IPM Workshop. J. Vos and P. Neuenschwander, eds. CPL Press, Newbury, UK.

17. Konam, J. K., and Guest, D. I. 2002. Leaf litter mulch reduces the survival of Phytophthora palmivora under cocoa trees in Papua New Guinea. Aust. Plant Pathol. 31:381-383.

18. Konam, J. K., and Guest, D. I. 2004. Role of flying beetles (Coleoptera: Scolytidae and Nitidulae) in the spread of Phytophthora pod rot of cocoa in Papua New Guinea. Aust. Plant Pathol. 33:55-59.

19. McMahon, P., Abdul W., Agung, W. S., Arief, I., Agus, P., Endang S., Yohannes, J., Sri, S., Suntoro, Endang, M., Muhammad, I., Muhammad, H., Darna, I., Lambert, S., Guest, D., and Keane, P. 2006. Selection for Quality and Resistance to Phytophthora Pod Rot, Cocoa Pod Borer and Vascular-Streak Dieback in Cocoa in Sulawesi. 15th International Cocoa Research Conference, San Jose, Costa Rica.

20. Ndoumbe-Nkeng, M., Cilas, C., Nyemb, E., Nyasse, S., Bieysse, D., Flori, A., and Sache, I. 2004. Impact of removing diseased pods on cocoa black pod caused by Phytophthora megakarya and on cocoa production in Cameroon. Crop Prot. 23:415-424.

21. Nyasse, S., Efombagn, M. I. B., Kébé, B. I., Tahi, M., Despreaux, D., and Cilas, C. 2007. Integrated management of Phytophthora diseases on cocoa (Theobroma cacao L): Impact of plant breeding on pod rot incidence. Crop Prot. 26:40-45.

22. Opuku, I. Y., Appiah, A. A., and Akrofi, A. Y. 2000. Phytophthora megakarya: A potential threat to the cocoa industry in Ghana. Ghana J. Agric. Sci. 33:237-248

23. Opoku, I. Y., Akrofi, A. Y., and Appiah, A. A. 2007. Assessment of sanitation and fungicide application directed at cocoa tree trunks for the control of Phytophthora black pod infections in pods growing in the canopy. Eur. J. Plant Pathol. 117:167-175.

24. Tahi, G. M., Kebe, B. I., Sangare, A., Cilas, C., and Eskes, A. B. 2007. Foliar resistance of cacao (Theobroma cacao) to Phytophthora palmivora as an indicator of pod resistance in the field: The effect of light intensity and time of day of leaf collection. Plant Pathol. 56:219-226. 